\title{
Reference evapotranspiration estimation by the Irrigameter in Southern Tocantins State, Brazil
}

\author{
Luan B. Giovanelli ${ }^{1}$, Rubens A. Oliveira ${ }^{1}$, Jair C. Oliveira-Filho ${ }^{2}$, \\ Júlio C. M. Baptestini ${ }^{1}$, Fábio T. Delazari ${ }^{3} \&$ Gilberto C. Sediyama ${ }^{1}$ \\ ${ }^{1}$ Universidade Federal de Viçosa/Departamento de Engenharia Agrícola. Viçosa, MG. E-mail: luanbg22@hotmail.com (Corresponding author); \\ rubens@ufv.br; jcbaptestini@yahoo.com.br; g.sediyama@ufv.br \\ ${ }^{2}$ Universidade Federal do Tocantins/Departamento de Agronomia. Gurupi, TO. E-mail: jair@uft.edu.br \\ ${ }^{3}$ Universidade Federal de Viçosa/Departamento de Fitotecnia. Viçosa, MG. E-mail: fabiodelazari@gmail.com
}

Key words:

irrigation management

irrigated agriculture

evaporator

\begin{abstract}
A B S T R A C T
The choice for the most appropriate method to estimate evapotranspiration depends on the availability of meteorological data, required level of precision and cost of equipment acquisition. For this estimate, the Irrigameter is simple to operate, precise and economically viable to farmers. In addition, it collaborates in the application of the necessary water depth to crops, thus avoiding unnecessary energy consumption, environmental degradation, and increasing crop yield and improving crop quality. In this context, the objective of this research was to estimate the reference evapotranspiration using the Irrigameter, for the climatic conditions of the Southern Tocantins state, Brazil. The experimental design was completely randomized with Irrigameters operating with seven water heights in the evaporator, as treatments, with three replicates. The reference evapotranspiration was obtained by FAO-56 Penman-Monteith method. For the analyzed climatic conditions, the water height in the evaporator recommended to estimate the reference evaporation in the spring is $3.4 \mathrm{~cm}$; summer, $4.0 \mathrm{~cm}$; fall, $3.8 \mathrm{~cm}$; and winter, $2.3 \mathrm{~cm}$.
\end{abstract}

\section{Palavras-chave:} manejo da irrigação agricultura irrigada evaporatório

\section{Estimativa da evapotranspiração de referência pelo Irrigâmetro no Sul do Estado do Tocantins}

\begin{abstract}
R E S U M O
A escolha do método mais apropriado para estimar a evapotranspiração depende da disponibilidade de dados meteorológicos, do nível de precisão exigido e do custo de aquisição dos equipamentos. Para tal estimativa, o Irrigâmetro é de simples operação, preciso e economicamente viável aos produtores rurais, haja vista que colabora para a aplicação da lâmina de água necessária às culturas, evitando o consumo desnecessário de energia e a degradação do meio ambiente, além de aumentar a produtividade e melhorar a qualidade das culturas. Neste contexto, objetivou-se, por esta pesquisa, estimar a evapotranspiração de referência utilizando o Irrigâmetro, para as condições climáticas do Sul do Estado do Tocantins. O delineamento experimental foi inteiramente casualizado com Irrigâmetros operando com sete alturas da água no evaporatório do aparelho, representando os tratamentos, e três repetições. A evapotranspiração de referência foi obtida pelo método de Penman-Monteith - FAO 56. Para as condições climáticas analisadas, a altura da água recomendada no evaporatório do aparelho para estimar a evapotranspiração de referência na primavera é $3,4 \mathrm{~cm}$; no verão, $4,0 \mathrm{~cm}$; no outono, $3,8 \mathrm{~cm}$ e no inverno, $2,3 \mathrm{~cm}$.
\end{abstract}




\section{INTRODUCTION}

In all the world, $18 \%$ of the agricultural area, which corresponds to 275 million ha, is irrigated (Nobre et al., 2010). These cultivated areas, where irrigated agriculture techniques are practiced, achieve a physical yield higher than two fifths of the total agricultural production (Christofidis, 2013). The practice of irrigation is considered as an alternative of guarantee in the agricultural production (Fernández-Cirelli et al., 2009; Fernandes et al., 2010); however, in most of the irrigated area in Brazil, it is common to observe the absence of rational water management.

In this context, information on reference evapotranspiration that leads to the estimate of the evapotranspiration of the crops becomes important tool in irrigation management (Araújo et al., 2007; Souza et al., 2009).

According to Tagliaferre et al. (2014; 2015), the Irrigameter invented (its patent is filed in the National Institute of Industrial Property - INPI - under the number PI05024889) and developed at the Federal University of Viçosa (UFV) is an evapo-pluviometric device to be used in irrigation management, to optimize water use in irrigated agriculture, which can be used to estimate the reference evapotranspiration (Tagliaferre et al., 2012b; Oliveira et al., 2008; 2011a;b).

In this context, this study aimed to establish, for each season of the year, the water height in the evaporator of the Irrigameter, for the device to estimate the reference evapotranspiration $\left(\mathrm{ET}_{0}\right)$ under the climatic conditions of the Southern Tocantins state.

\section{Material ANd Methods}

The study was carried out in the experimental area of the Federal University of Tocantins (UFT), on the University Campus of Gurupi, TO, Brazil. The geographic coordinates of the municipality are $11^{\circ} 45^{\prime} \mathrm{S}$ and $49^{\circ} 03^{\prime} \mathrm{W}$, at an altitude of $287 \mathrm{~m}$. In this area, 21 Irrigameters were installed at spacing of $3.0 \times 3.0 \mathrm{~m}$.

The meteorological station installed in the experimental area is a DAVIS, model Vantage Pro II. The values of reference evapotranspiration $\left(\mathrm{ET}_{0}\right)$ were obtained by the FAO-56 Penman-Montheith method, through the computer program REF-ET (Allen, 2000), using data of solar radiation, relative humidity, wind speed and air temperature.

The period of data collection started in September 2008 and ended in September 2011, thus resulting in three years of observation. The data collection for the treatment in which the water height in the evaporator was $1 \mathrm{~cm}$ started in September 2010 and ended along with the others, encompassing one year of data. Rainy days were removed from the study, since the rainfall alters the water height in the evaporator of the device and the return to the original height did not always occur immediately after rainfall.

The evapotranspired depth estimated by the Irrigameter was read in the feeding tube of the device, which is graduated in millimeters. Such reading was daily performed at 9 a.m. and the daily evapotranspiration estimated by the Irrigameter was obtained by the difference of level inside the feeding tube of the device, in the interval of $24 \mathrm{~h}$.
The experiment was set in a completely randomized design, guaranteed by a drawn, with seven water heights in the evaporator of the device representing the treatments, with three replicates, totaling 21 Irrigameters. The following water heights were used as treatments: $\mathrm{H} 1=1 \mathrm{~cm} ; \mathrm{H} 2=2 \mathrm{~cm} ; \mathrm{H} 3=3 \mathrm{~cm} ; \mathrm{H} 4=4 \mathrm{~cm} ; \mathrm{H} 5$ $=5 \mathrm{~cm} ; \mathrm{H} 6=6 \mathrm{~cm}$ and $\mathrm{H} 7=7 \mathrm{~cm}$, taken from a reference level in an ascending scale, existing inside the evaporator of the device.

The conical shape of the evaporator allows the surface exposed to the atmosphere to increase as the water height increases (Figure 1).

The Irrigameter coefficient $\left(\mathrm{K}_{\mathrm{I}}\right)$ represents the ratio between the estimate of evapotranspiration obtained in the Irrigameter $\left(\mathrm{ET}_{\mathrm{I}}\right)$ and the reference evapotranspiration $\left(\mathrm{ET}_{0}\right)$. Thus, the value of the angular coefficient $\left(\beta_{1}\right)$ was attributed to the $\mathrm{K}_{\mathrm{I}}$, not considering the constant $\beta_{0}$ in the model.

For each treatment, one $\mathrm{K}_{\mathrm{I}}$ coefficient was determined per season of the year, using Eq. 1, which establishes the relationship between the evapotranspiration estimated by the Irrigameter $\left(\mathrm{ET}_{\mathrm{I}}\right)$ and the reference evapotranspiration $\left(\mathrm{ET}_{0}\right)$ :

$$
\mathrm{K}_{\mathrm{I}}=\frac{\sum \mathrm{ET}_{0} \mathrm{ET}_{\mathrm{I}}}{\sum \mathrm{ET}_{0}{ }^{2}}
$$

where:

$\mathrm{K}_{\mathrm{I}} \quad$ - irrigameter coefficient, dimensionless;

$\mathrm{ET}_{\mathrm{I}}$ - evapotranspiration estimated by the Irrigameter, $\mathrm{mm} \mathrm{d}^{-1}$; and,

$\mathrm{ET}_{0}$ - reference evapotranspiration, $\mathrm{mm} \mathrm{d}^{-1}$.

The water height in the evaporator, which corresponds to $K_{I}=1$, i.e., the height adjusted for the direct estimate of reference evapotranspiration $\left(\mathrm{ET}_{0}\right)$, was determined by the fit of the equations that relate the water heights in the evaporator and the respective coefficients of the Irrigameter, obtained for the different seasons of the year.

The data were subjected to analyses of variance and regression, using the statistical software SAEG (Ribeiro Junior, 2001). The regression models were selected based on the significance of the regression coefficients by t-test, at 0.05 probability level.

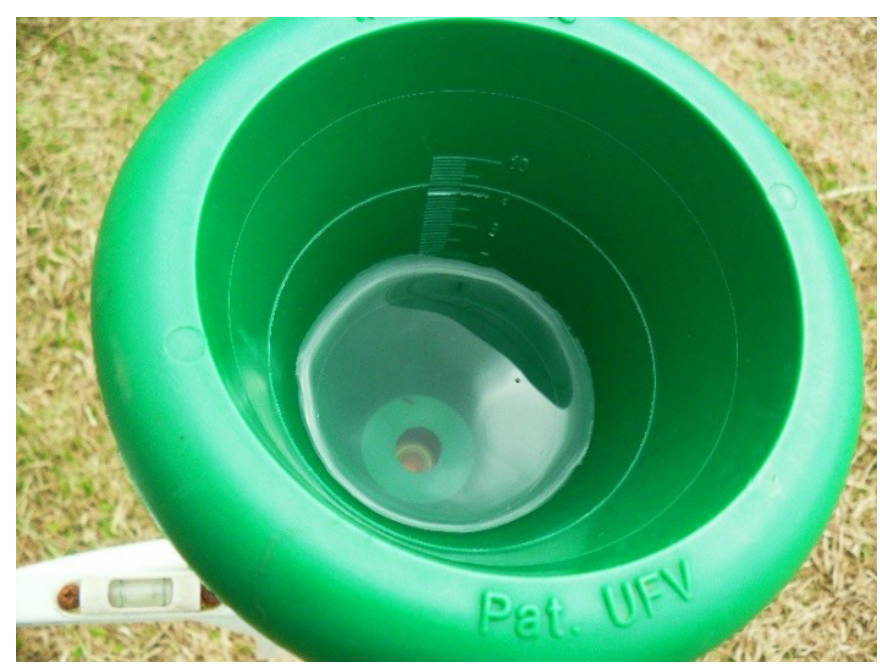

Figure 1. Water exposed to the atmosphere inside the evaporator 
Table 1 shows the means of the main meteorological elements observed along the experiment.

Table 1. Mean values of maximum and minimum temperature, relative air humidity, wind speed and solar radiation during the different seasons of the year, for the Southern region of the Tocantins state

\begin{tabular}{lrccc}
\hline \multicolumn{1}{c}{$\begin{array}{c}\text { Meteorological } \\
\text { element }\end{array}$} & \multicolumn{4}{c}{ Season of the year } \\
\cline { 2 - 5 } Maximum temperature $\left({ }^{\circ} \mathrm{C}\right)$ & 32.94 & 31.35 & 32.07 & 34.58 \\
Minimum temperature $\left({ }^{\circ} \mathrm{C}\right)$ & 22.37 & 22.29 & 20.57 & 16.92 \\
Relative air humidity $(\%)$ & 73.46 & 82.33 & 77.44 & 57.79 \\
Mean wind speed $\left(\mathrm{m} \mathrm{s}^{-1}\right)$ & 0.83 & 0.53 & 0.41 & 0.76 \\
Solar radiation $\left(\mathrm{MJ} \mathrm{m}^{-2} \mathrm{~d}^{-1}\right)$ & 17.39 & 17.47 & 16.26 & 18.46 \\
\hline
\end{tabular}

\section{Results AND Discussion}

Table 2 shows the summary of the analysis of variance of the $\mathrm{ET}_{\mathrm{I}}$ data for the different water heights in the evaporator. It is possible to observe that the evapotranspiration estimated by the Irrigameter was significantly affected by the increase of water height in the evaporator.

Table 3 shows the $K_{I}$ values and the mean values of the evapotranspiration estimated by the Irrigameter $\left(\mathrm{ET}_{\mathrm{I}}\right)$ for each treatment, as well as the mean reference evapotranspiration $\left(\mathrm{ET}_{0}\right)$ for the analyzed season.

In Table 3, it is possible to observe that, in the spring, the best condition in which the Irrigameter must be to estimate the reference evapotranspiration is that in which the water height in the evaporator is between 3 and $4 \mathrm{~cm}$. The mean value of $\mathrm{ET}_{0}$ determined by the standard method was equal to $4.31 \mathrm{~mm} \mathrm{~d}^{-1}$, which is comprehended between the mean $\mathrm{ET}_{\mathrm{I}}$ obtained when the water height inside the evaporator was equal to $3 \mathrm{~cm}$ (3.94 $\left.\mathrm{mm} \mathrm{d}^{-1}\right)$ and $4 \mathrm{~cm}\left(4.64 \mathrm{~mm} \mathrm{~d}^{-1}\right)$.

In the summer, the best condition for the Irrigameter to estimate the reference evapotranspiration is when the water height in the evaporator is close to $4 \mathrm{~cm}$. The mean value of $\mathrm{ET}_{0}$, determined by the standard method, was equal to 3.97 $\mathrm{mm} \mathrm{d}^{-1}$, which is very close to the mean $\mathrm{ET}_{\mathrm{I}}$ of the treatment $\mathrm{H} 4\left(4.05 \mathrm{~mm} \mathrm{~d}^{-1}\right)$.

It was also observed that the water height that best estimates the $\mathrm{ET}_{0}$ values in the autumn season is comprehended between 3 and $4 \mathrm{~cm}$, as occurred in the spring. The Irrigameter, as in the spring, underestimated the value of $\mathrm{ET}_{0}$ for the heights 1 , 2 and $3 \mathrm{~cm}$ and overestimated it for the others.

During the winter, it can be observed that the water height in the evaporator that best represents the situation to estimate the reference evapotranspiration is comprehended between 2 and $3 \mathrm{~cm}$. The mean value of $\mathrm{ET}_{0}\left(4.14 \mathrm{~mm} \mathrm{~d}^{-1}\right)$ is between the mean values of $\mathrm{ET}_{\mathrm{I}}$ estimated for the heights of 2 and $3 \mathrm{~cm}$. Only the treatments $\mathrm{H} 1$ and $\mathrm{H} 2$ underestimated $\mathrm{ET}_{0}$, while the others overestimated it.

Table 2. Summary of the analysis of variance of the ET, data for the water heights in the evaporator

\begin{tabular}{lcc}
\hline \multicolumn{1}{c}{ Source of variation } & DF & MS \\
Water heights & 6 & $11.62^{\star \star}$ \\
Residual & 14 & 0.06 \\
Coefficient of variation (\%) & & 5.92 \\
\hline \multirow{2}{*}{. }
\end{tabular}

** Significant at 0.01 probability by F test; DF - Degrees of freedom; MS - Mean square
Table 3. Water height in the evaporator, $\mathrm{K}_{1}$ and mean value

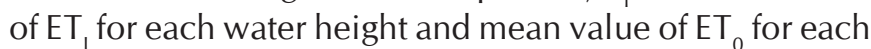
season of the year

\begin{tabular}{|c|c|c|c|c|c|}
\hline \multirow{2}{*}{ Season } & \multirow{2}{*}{ Treatment } & \multirow{2}{*}{$\begin{array}{c}\text { Water } \\
\text { height (cm) }\end{array}$} & \multirow{2}{*}{$K_{1}$} & $\mathrm{ET}_{1}$ & $\mathrm{ET}_{0}$ \\
\hline & & & & \multicolumn{2}{|c|}{$\left(\mathrm{mm} \mathrm{d}^{-1}\right)$} \\
\hline \multirow{7}{*}{ Spring } & $\mathrm{H} 1$ & 1 & 0.45 & 1.56 & \multirow{7}{*}{4.31} \\
\hline & $\mathrm{H} 2$ & 2 & 0.70 & 2.99 & \\
\hline & H3 & 3 & 0.92 & 3.94 & \\
\hline & $\mathrm{H} 4$ & 4 & 1.09 & 4.64 & \\
\hline & H5 & 5 & 1.29 & 5.64 & \\
\hline & $\mathrm{H} 6$ & 6 & 1.62 & 6.95 & \\
\hline & $\mathrm{H} 7$ & 7 & 1.79 & 7.72 & \\
\hline \multirow{7}{*}{ Summer } & $\mathrm{H} 1$ & 1 & 0.39 & 1.56 & \multirow{7}{*}{3.97} \\
\hline & $\mathrm{H} 2$ & 2 & 0.60 & 2.48 & \\
\hline & H3 & 3 & 0.80 & 3.29 & \\
\hline & $\mathrm{H} 4$ & 4 & 0.99 & 4.05 & \\
\hline & H5 & 5 & 1.20 & 4.91 & \\
\hline & $\mathrm{H} 6$ & 6 & 1.45 & 5.95 & \\
\hline & $\mathrm{H} 7$ & 7 & 1.63 & 6.72 & \\
\hline \multirow{7}{*}{ Autumn } & $\mathrm{H} 1$ & 1 & 0.53 & 1.80 & \multirow{7}{*}{3.4} \\
\hline & $\mathrm{H} 2$ & 2 & 0.67 & 2.30 & \\
\hline & H3 & 3 & 0.85 & 2.91 & \\
\hline & $\mathrm{H} 4$ & 4 & 1.07 & 3.67 & \\
\hline & $\mathrm{H} 5$ & 5 & 1.34 & 4.57 & \\
\hline & $\mathrm{H} 6$ & 6 & 1.69 & 5.77 & \\
\hline & $\mathrm{H} 7$ & 7 & 1.89 & 6.46 & \\
\hline \multirow{7}{*}{ Winter } & $\mathrm{H} 1$ & 1 & 0.80 & 3.19 & \multirow{7}{*}{4.14} \\
\hline & $\mathrm{H} 2$ & 2 & 0.90 & 3.73 & \\
\hline & H3 & 3 & 1.10 & 4.58 & \\
\hline & $\mathrm{H} 4$ & 4 & 1.42 & 5.88 & \\
\hline & H5 & 5 & 1.72 & 7.16 & \\
\hline & $\mathrm{H} 6$ & 6 & 2.09 & 8.68 & \\
\hline & $\mathrm{H} 7$ & 7 & 2.28 & 9.53 & \\
\hline
\end{tabular}

Figure 2 shows the values of $\mathrm{K}_{\mathrm{I}}$ as a function of the water heights in the evaporator of the device, for the four analyzed seasons.

In Figure 2, it is possible to observe that the Irrigameter coefficient increases exponentially with the increment of water height in the evaporator in the winter and autumn seasons, while in the spring and summer seasons the Irrigameter coefficient increased linearly with the increment of water height in the evaporator.

Tagliaferre et al. (2012a) observed that this increase was exponential for all seasons of the year, in a study conducted in the region of Vitória da Conquista, BA. Caixeta (2009), on the other hand, found quadratic variation of the Irrigameter coefficient for the climatic conditions of the 'Zona da Mata' in Minas Gerais in the period from March to October 2008.

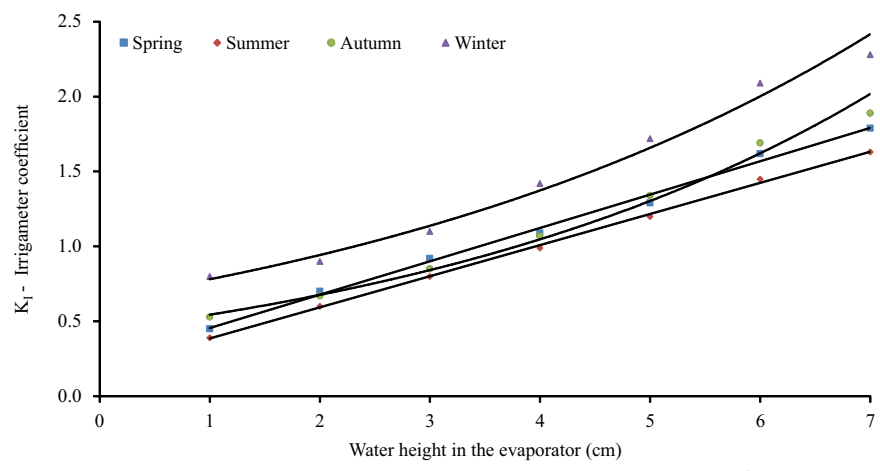

Figure 2. Irrigameter coefficient as a function of the water heights in the evaporator, for the four seasons of the year 
In addition, Figure 2 also shows that the winter season led to the highest values of the Irrigameter coefficient. This fact is due to the higher values of maximum temperature and solar radiation and low relative air humidity during this season (Table 1), causing high values of $\mathrm{ET}_{\mathrm{I}}$ in the period for all heights evaluated (Table 3). The lowest values of the coefficient occurred in the summer, which can be explained by the lower mean value of maximum temperature and higher mean relative humidity of the years.

For the water height of $1 \mathrm{~cm}$ in the evaporator, the Irrigameter coefficients showed the lowest values of the entire experimental period and small variation between the analyzed seasons. Always when the water height decreased, remaining farther from the edge of the evaporator, there was a decrease in the liquid surface exposed to the atmosphere and, consequently, lower value of the estimate of evapotranspiration by the Irrigameter.

Table 4 shows the regression equations that must be used to determine the water heights in the evaporator of the Irrigameter and their determination coefficients, for each season of the year.

Due to the good fit of the equations, evidenced by the significances of the regression coefficients and high determination coefficients, the equations obtained for each season can be used to determine the water heights in the evaporator of the Irrigameter, so that it directly estimates the value of reference evapotranspiration $\left(\mathrm{K}_{\mathrm{I}}=1\right)$ or crop evapotranspiration for any development stage, making in this case $\mathrm{K}_{\mathrm{I}}$ equal to Kc. The water heights in the evaporator of the Irrigameter recommended to estimate the reference evapotranspiration of the Southern region of Tocantins for the spring, summer, autumn and winter are 3.4, $4.0,3.8$ and $2.3 \mathrm{~cm}$, respectively.

According to the studies conducted by Oliveira et al. (2011b), during the months from August 2008 and May 2009, for the region of Alto Paranaíba-MG, the analysis of the data for the entire experimental period showed that, to estimate reference evapotranspiration using the Irrigameter, the device must be operated with water height of $4.1 \mathrm{~cm}$ in the evaporator.

According to Tagliaferre et al. (2012b), when operated with water level of $3 \mathrm{~cm}$, the Irrigameter showed satisfactory performance in the estimate of reference evapotranspiration in Guanambi-BA, between April 2009 and January 2010. Oliveira et al. (2011a) elucidated that, to obtain the estimate of reference evapotranspiration under the climatic conditions of Jaíba-MG, it is recommended to use the device equipped with evaporator operating with water height of $3.7 \mathrm{~cm}$.

Table 4. Fitted regression equations for the determination of water heights in the evaporator of the Irrigameter for each season of the year

\begin{tabular}{|c|c|c|}
\hline $\begin{array}{c}\text { Season } \\
\text { of the year }\end{array}$ & Equation & $\begin{array}{l}\text { Determination } \\
\text { coefficient }\left(\mathrm{R}^{2}\right)\end{array}$ \\
\hline Spring & $\hat{y}=0.2222^{* * *} X+0.2348$ & 0.99 \\
\hline Summer & $\hat{y}=0.2070^{\star \star \star} X+0.1803$ & 0.99 \\
\hline Autumn & $\hat{y}=0.4382 e 0.2182 X$ & 0.99 \\
\hline Winter & $\hat{y}=0.6455 \mathrm{e} 0.1889 \mathrm{X}$ & 0.99 \\
\hline
\end{tabular}

${ }^{* * \star}$ Significant at 0.01 probability level by t-test

\section{Conclusions}

The water heights recommended in the evaporator of the Irrigameter, so that it estimates the reference evapotranspiration in the Southern region of the Tocantins state, for spring, summer, autumn and winter are $3.4,4.0,3.8$ and $2.3 \mathrm{~cm}$, respectively.

\section{Literature Cited}

Allen, R. G. REF-ET: Reference evapotranspiration calculator Version 2.1. Kimberly: Idaho University, 2000. 82p.

Araújo, W. F.; Costa, A. A.; Santos, A. E. dos. Comparação entre métodos de estimativas da evapotranspiração de referencia $\left(\mathrm{ET}_{0}\right)$ para Boa Vista-RR. Revista Caatinga, v.20, p.84-88, 2007.

Caixeta, S. P. Efeitos de elementos meteorológicos na evapotranspiração estimada pelo Irrigâmetro nas condições climáticas da Zona da Mata mineira. Viçosa: UFV, 2009. 51p. Dissertação Mestrado

Christofidis, D. Água, irrigação e agropecuária sustentável. Revista de Política Agrícola, v.22, p.115-127, 2013.

Fernandes, L. A. C.; Ribeiro, M. R.; Oliveira, L. B.; Ferreira, R. F. A. L. Caracterização e classificação de solos de uma litotoposseqüência do Projeto Xingó-SE. Revista Brasileira de Ciências Agrárias, v.5, p.192-201, 2010. https://doi.org/10.5039/agraria.v5i2a675

Fernández-Cirelli, A.; Arumí, J. L.; Rivera, D.; Boochs, P. W. Environmental effects of irrigation in arid and semi-arid regions. Chilean Journal Agricultural Research, v.69, p.27-40, 2009. https:// doi.org/10.4067/S0718-58392009000500004

Nobre, R. G.; Gheyi, H. R.; Soares, F. A. L.; Andrade, L. O. de; Nascimento, E. C. S. Produção do girassol sob diferentes lâminas com efluentes domésticos e adubação orgânica. Revista Brasileira de Engenharia Agrícola e Ambiental, v.14, p.747-754, 2010. https://doi.org/10.1590/S1415-43662010000700010

Oliveira, E. M.; Oliveira, R. A.; Paula, A. L. T. de; Baptestini, J. C. M.; Caixeta, S. P.; Giovanelli, L. B. Desempenho do Irrigâmetro no manejo da irrigação no Perímetro Irrigado do Jaíba, MG. Revista Ambiente e Água, v.6, p.157-164, 2011a. https://doi.org/10.4136/ ambi-agua.181

Oliveira, E. M.; Oliveira, R. A.; Sediyama, G. C.; Cecon, P. R.; Drumond, L. C. D. Análise do coeficiente e o desempenho do Irrigâmetro e a influência dos elementos do clima na estimativa da evapotranspiração. Engenharia na Agricultura, v.19, p.348-360, 2011b. https://doi.org/10.13083/1414-3984.v19n04a07

Oliveira, R. A.; Tagliaferre, C.; Sediyama, G. C.; Materam, F. J.; Cecon, P. R. Desempenho do Irrigâmetro na estimativa da evapotranspiração de referência. Revista Brasileira de Engenharia Agrícola e Ambiental, v.12, p.166-173, 2008. https://doi. org/10.1590/S1415-43662008000200009

Ribeiro Junior, J. I. Análises estatísticas no SAEG. Viçosa: UFV, 2001.301p.

Souza, M. do S. M. de; Bezerra, F. M. L.; Viana, T. V. de A.; Teófilo, E. M.; Cavalcante, I. H. L. Evapotranspiração do maracujá nas condições do Vale do Curu. Revista Caatinga, v.22, p.11-16, 2009.

Tagliaferre, C.; Paula, A. de; Rocha, F. A.; Campos, W. V.; Guimarães, D. U. Influência dos elementos meteorológicos na evapotranspiração de referência estimada utilizando-se o Irrigâmetro no município de Guanambi-BA. Engenharia na Agricultura, v.23, p.251-260, 2015. https://doi.org/10.13083/1414-3984/reveng.v23n3p251-260

Tagliaferre, C.; Santos, L. da C.; Santos Neto, I. J. dos; Santos, T. J. dos; Rocha, F. A.; Guimarães, D. U. Estimativa da evapotranspiração de referência com uso do Irrigâmetro em Vitória da Conquista-BA. Irriga, v.17, p.28-38, 2012a. https://doi.org/10.15809/irriga.2012v17n1p28 
Tagliaferre, C.; Santos Neto, I. J.; Cotrim, C. E.; Rocha, F. A.; Santos, L. C. Desempenho do Irrigâmetro e de métodos de estimativa da evapotranspiração de referência para o município de GuanambiBA. Engenharia na Agricultura, v.20, p.544-553, 2012b. https:// doi.org/10.13083/1414-3984.v20n06a07
Tagliaferre, C.; Santos, L. da C.; Santos Neto, I. J. dos; Santos, T. J. dos; Rocha, F. A.; Silva, C. S. Ajuste e aplicação do Irrigâmetro no manejo da água de irrigação. Irriga, v.19, p.61-72, 2014. https:// doi.org/10.15809/irriga.2014v19n1p61 